\title{
US GEOLOGICAL SURVEY, MENLO PARK, CALIFORNIA RADIOCARBON MEASUREMENTS III
}

\section{STEPHEN W ROBINSON and DEBORAH A TRIMBLE}

US Geological Survey, Menlo Park, California 94025

The analyses in this list were performed between 1977 and 1979. The laboratory utilizes gas counting of carbon dioxide in counters installed 9.5 meters below the ground surface for background reduction. The reported results closely follow the guidelines of Stuiver and Polach (1977), although the standard error for analyses earlier than USGS-500 are based solely upon counting statistics and do not include uncertainty in voltage, pressure, temperature, and $\delta^{13} \mathrm{C}$.

\section{ACKNOWLEDGMENTS}

The authors gratefully acknowledge the technical assistance of Rod Mosely and John LeLange in the operation of the laboratory.

\section{GEOLOGIC SAMPLES}

Alaska

\section{USGS-48. Yukon Delta}

Basal peat ca $1.5 \mathrm{~m}$ below surface; E bank of Kawanak Pass $\left(62^{\circ} 55^{\prime}\right.$ $\mathrm{N}, 164^{\circ} 06^{\prime} \mathrm{W}$ ). Dates older part of modern lake of Yukon delta. Coll 1976 and subm by W R Dupré, Univ Houston, Texas.

\section{USGS-119. Black River}

$1350 \pm 80$

Basal peat from outcrop along Black R $\left(62^{\circ} 09^{\prime} \mathrm{N}, 164^{\circ} 59^{\prime} \mathrm{W}\right)$, ca $5 \mathrm{~km} \mathrm{NW}$ of village of New Knockhock. Dates time when Black $R$ was main course of Yukon R. Coll 1976 and subm by W R Dupré.

\section{USGS-50. Melatolik Creek}

Est $\delta^{1.3} C=-25 \%$ o

Basal peat from abandoned mid-channel bar along Melatolik Creek $\left(62^{\circ} 02^{\prime} \mathrm{N}, 165^{\circ} 14^{\prime} \mathrm{W}\right)$. Dates time when Melatolik Creek was main course of Yukon R. Coll 1976 and subm by W R Dupré.

\section{USGS-51. Kashunuk River}

$1200 \pm 60$

Log in basal peat exposed along $S$ bank of Kashunuk R $\left(61^{\circ} 32^{\prime} \mathrm{N}\right.$, $\left.164^{\circ} 46^{\prime} \mathrm{W}\right)$, ca $1 \mathrm{~km} \mathrm{~W}$ of Nuigalak Lake. Dates time when Kashunuk $R$ was main course of Yukon R. Coll 1976 and subm by W R Dupré.

\section{USGS-52. Panawat Spit}

Modern

Wood fragment from near base of sea cliff where Pleistocene marine terrace deposits are exposed, ca $4 \mathrm{~km} \mathrm{~N}$ of Dall Pt $\left(61^{\circ} 36^{\prime} \mathrm{N}, 166^{\circ} 10^{\prime} \mathrm{W}\right)$. Date indicates contamination by modern roots. Coll 1976 and subm W R Dupré. 


\section{USGS-215. Panawat Spit}

$$
\begin{array}{r}
\mathbf{5 0 7 0} \pm \mathbf{6 0} \\
\text { Est } \delta^{13} C=-25 \% \text { o }
\end{array}
$$

Peat ca $2 \mathrm{~m}$ from top of sea cliff, ca $4 \mathrm{~km} \mathrm{~N}$ of Dall Pt $\left(61^{\circ} 36^{\prime} \mathrm{N}\right.$, $\left.166^{\circ} 10^{\prime} \mathrm{W}\right)$. Probably dates filling of thaw lake on uplifted marine terrace deposits exposed in lower part of sea cliff. Coll 1977 and subm by W R Dupré.

\section{USGS-217. Manokinak River}

$1930 \pm 70$

Basl peat Ca 1.2m below top of cut bank along $\mathrm{N}$ side of Manokinak $\mathrm{R}\left(63^{\circ} 23^{\prime}\right.$ R $\left(63^{\circ} 23^{\prime} 32^{\prime \prime} \mathrm{N}, 164^{\circ} 31^{\prime} 41^{\prime \prime} \mathrm{W}\right)$. Dates time when Manokinak was major course of Yukon R. Coll 1977 and subm by W R Dupré.

\section{USGS-218. Kwikiuak}

$1800 \pm 90$ ridge/chenier plain S of modern Yuk low: $1890 \pm 85$ ). Coll 1977 and subm by W R Dupré.

\section{USGS-225. Black River}

$1550 \pm 80$ ridges within with with USGS-212, below: $1430 \pm 50$ ). Coll 1977 and subm by W R Dupré.

\section{USGS-226. Eleutak}

$2570 \pm 70$

Basal peat ca $0.8 \mathrm{~m}$ below top of cut bank on SW side of $\mathrm{kwemeluk}$ Pass $\left(62^{\circ} 29^{\prime} 08^{\prime \prime} \mathrm{N}, 164^{\circ} 51^{\prime} 45^{\prime \prime} \mathrm{W}\right)$, ca $6 \mathrm{~km} \mathrm{~S}$ of Sheldon Pt. Dates one of oldest beach ridges in chenier plain $S$ of modern Yukon delta (compares with USGS-214, below: $2420 \pm 80$ ). Coll 1977 and subm by W R Dupré.

\section{USGS-53. Black River}

$1890 \pm 90$

Basal peat along SW side of Black R, ca $2.5 \mathrm{~km}$ NW of Uksuk $\left(62^{\circ}\right.$ $\left.19^{\prime} \mathrm{N}, 165^{\circ} 12^{\prime} \mathrm{W}\right)$. Dates middle of chenier plain/beach ridge complex that postdates most of time Black R was main course of Yukon R. Coll 1976 and subm by W R Dupré.

\section{USGS-212. Sheldon Point}

$1430 \pm 50$ luk Pass $\left(62^{\circ} 2^{\circ}\right.$ eat ca $2 \mathrm{~m}$ below surface, exposed on $\mathrm{S}$ bank of Kweme年 age of one of youngest well-developed beach ridges in chenier plain $S$ of modern Yukon delta. Coll 1977 and subm by W R Dupré.

\section{USGS-213. Emmonak}

$600 \pm 70$

Wood ca $1.5 \mathrm{~m}$ from top of cut bank, $\mathrm{N}$ side of Kwiguk Pass $\left(62^{\circ} 45^{\prime}\right.$ $\left.30^{\prime \prime} \mathrm{N}, 164^{\circ} 30^{\prime} \mathrm{W}\right)$ at village of Emmonak. Dates intermediate age part 
of modern Yukon delta, indicating it is relatively young geol feature (of USGS-48). Coll 1977 and subm by W R Dupré.

$$
2420 \pm 80
$$

\section{USGS-2: 14. Kwikiuak Pass}

Est $\delta^{13} \mathrm{C}=-25 \%$

Wood from SE side of Kwikiuak Pass $\left(62^{\circ} 37^{\prime} 20^{\prime \prime} \mathrm{N}, 164^{\circ} 40^{\prime} 22^{\prime \prime} \mathrm{W}\right)$, ca $13 \mathrm{~km} \mathrm{NE}$ of Sheldon Pt. Dates one of oldest beach ridges in chenier plain $\mathrm{S}$ of modern Yukon delta. Also marks period of max transgression of Holocene shoreline in area. Coll 1977 and subm by W R Dupré.

\section{USGS-352. Norton Sound}

$13,770 \pm 210$

Lenses of peat, from $1.4 \mathrm{~m}$ below top of vibracore taken $20 \mathrm{~m}$ below $\mathrm{msl}, 40 \mathrm{~km} \mathrm{~S}$ of Nome $\left(64^{\circ} 10^{\prime} 6^{\prime \prime} \mathrm{W}, 165^{\circ} 27^{\prime} 45^{\prime \prime} \mathrm{N}\right)$. Dates top of Pleistocene freshwater sediment, below Holocene marine transgressive sediment. Coll 1977 and subm by C H Nelson, USGS.

\section{USGS-353. Norton Sound}

$3070 \pm 40$

Peat laminations, 3 to $9 \mathrm{~cm}$ below top of boxcore taken $10 \mathrm{~m}$ below msl, $30 \mathrm{~km} \mathrm{~W}$ of Yukon R delta $\left(62^{\circ} 58^{\prime} 12^{\prime \prime} \mathrm{W}, 165^{\circ} 16^{\prime} 15^{\prime \prime} \mathrm{N}\right)$. Dates storm surges in N Bering Sea near Yukon delta. Date may be anomalously old due to epiclastic nature of peat recycled to offshore locations from original onshore delta sources. Coll 1977 and subm by C H Nelson.

\section{USGS-354. Norton Sound}

$$
3590 \pm 140
$$

Peat layers, interbedded with silt, from 13 to $16 \mathrm{~cm}$ below top of boxcore taken $10 \mathrm{~m}$ below msl, $40 \mathrm{~km}$ NW of Yukon R delta $\left(63^{\circ} 31^{\prime} 30^{\prime \prime} \mathrm{W}\right.$, $165^{\circ} 43^{\prime} 37^{\prime \prime} \mathrm{N}$ ). Dates storm surges in N Bering Sea near Yukon delta. Date may be anomalously old due to epiclastic nature of peat recycled to offshore locations from original onshore delta sources. Coll 1977 and subm by $\mathrm{C} \mathrm{H}$ Nelson.

\section{USGS-356. Northern Bering Sea}

$$
\begin{array}{r}
16,540 \pm 200 \\
\text { Est } \delta^{13} C=-25 \% \text { o }
\end{array}
$$

Peat layer with wood fragments, from $120 \mathrm{~cm}$ below top of vibracore taken $28 \mathrm{~m}$ below msl $30 \mathrm{~km}$ W of Port Clarence spit $\left(65^{\circ} 7^{\prime} 14^{\prime \prime} \mathrm{W}, 167^{\circ}\right.$ $30^{\prime} 49^{\prime \prime} \mathrm{N}$ ). Dates top of Pleistocene freshwater sediment, below Holocene marine sediment in region subject to uplift. Coll 1977 and subm by $\mathrm{C} \mathrm{H}$ Nelson.

\section{USGS-357. Northern Bering Sea}

$$
15,450 \pm 250
$$

Peaty silt, $40 \mathrm{~cm}$ below top of vibracore taken $31 \mathrm{~m}$ below msl, $35 \mathrm{~km}$ $\mathrm{W}$ of Port Clarence spit $\left(65^{\circ} 7^{\prime} 51^{\prime \prime} \mathrm{W}, 167^{\circ} 35^{\prime} 45^{\prime \prime} \mathrm{N}\right)$. Dates top of Pleistocene freshwater sediment, below Holocene marine sediment in region subject to uplift. Coll 1977 and subm by C H Nelson. 


\section{USGS-358. Norton Sound}

$$
\begin{array}{r}
11,570 \pm 130 \\
\text { Est } \delta^{1 s} C=-25 \% \text { o }
\end{array}
$$

Peat layers, 85 to $90 \mathrm{~cm}$ below top of vibracore taken $17 \mathrm{~m}$ below msl, $35 \mathrm{~km}$ NW of Stuart I. $\left(63^{\circ} 53^{\prime} 6^{\prime \prime} \mathrm{W}, 163^{\circ} 1^{\prime} 26^{\prime \prime} \mathrm{N}\right)$. Dates top of Pleistocene freshwater sediment, below Holocene marine transgressive sediment. Coll 1977 and subm by C H Nelson.

\section{Kealok Creek series}

From bluff $27 \mathrm{~m}$ high on Kealok Creek in eolian sand $\left(70^{\circ} 22^{\prime} 18^{\prime \prime} \mathrm{N}\right.$, $\left.153^{\circ} 12^{\prime} 12^{\prime \prime} \mathrm{W}\right)$. Dates episodes of dune activity and stabilization. USGS377 and -378 date rapid eolian accretion; USGS-448 and -379 bracket episode of stabilization; USGS-380 dates brief interval of stabilization following renewed activity. Coll 1977 and subm by L D Carter, USGS.

\section{USGS-380.}

$940 \pm 110$

Peaty sand from bed, $15 \mathrm{~cm}$ thick, $2 \mathrm{~m}$ below top of bluff.

USGS-379.

$5250 \pm 80$

Peat from top of peat bed, $50 \mathrm{~cm}$ thick, that occurs $4 \mathrm{~m}$ below top of bluff.

USGS-448.

$8180 \pm 80$ bluff.

Peat from base of peat bed, $50 \mathrm{~cm}$ thick, that occurs $4 \mathrm{~m}$ below top of

USGS-378.

$10,700 \pm 120$

Salix sp (willow) wood in growth position $6 \mathrm{~m}$ below top of bluff.

USGS-377.

$10,980 \pm 80$

Salix sp (willow) wood from $10 \mathrm{~m}$ below top of bluff.

\section{Chipp River series}

From bluff $15 \mathrm{~m}$ high on Chipp R ( $\left.70^{\circ} 22^{\prime} 30^{\prime \prime} \mathrm{N}, 155^{\circ} 03^{\prime} \mathrm{W}\right)$. Dates alluvium of former flood plain of Chipp R. Coll 1977 and subm by L D Carter.

USGS-449.

Wood in growth position $9 \mathrm{~m}$ above base of bluff.

USGS-456.

Detrital wood (Salix sp) $12.5 \mathrm{~m}$ above base of bluff.

\section{Ikpikpuk River series}

From alluvium exposed in bluff $16 \mathrm{~m}$ high on Ikpikpuk $\mathrm{R}\left(69^{\circ} 42^{\prime}\right.$ $\left.36^{\prime \prime} \mathrm{N}, 154^{\circ} 52^{\prime} 36^{\prime \prime} \mathrm{W}\right)$. Dates periods of alluviation and alluvial terrace formation. Coll 1977 and subm by L D Carter. 


\section{USGS-457.}

Detrital wood $4.5 \mathrm{~m}$ below top of bluff.

USGS-632.

Detrital wood $1 \mathrm{~m}$ above base of bluff.

\section{USGS-807.}

$13,570 \pm 120$ Est $\delta^{13} C=-25 \%$ o

Limb element of Mammuthus sp 2m above base of bluff; one of many bones from single individual of this $\mathrm{sp}$ that were present over lower $3 \mathrm{~m}$ of surface of bluff.

\section{USGS-316. Hidden Lake, Kenai Peninsula}

$6040 \pm 80$

Est $\delta^{13} \mathrm{C}=-25 \%$ o

Carbonaceous sediments from core HL-4-M between 122 to $130 \mathrm{~cm}$ below bottom of Hidden Lake $\left(60^{\circ} 29^{\prime} 37^{\prime \prime} \mathrm{N}, 150^{\circ} 22^{\prime} 38^{\prime \prime} \mathrm{W}\right)$. Calibrates varve counts in older part of core and dates volcanic ash beds derived from volcanoes on Alaskan Peninsula. Sample helps date time of deglaciation of area. Coll 1977 by J D Sims and M J Rymer; subm by J D Sims, USGS.

\section{USGS-317. Hidden Lake, Kenai Peninsula}

$10,380 \pm 240$

Est $\delta^{13} \mathrm{C}=-25 \%$ o

Carbonaceous sediments from core HL-4-M between 205 and $215 \mathrm{~cm}$ below bottom of Hidden Lake $\left(60^{\circ} 29^{\prime} 37^{\prime \prime} \mathrm{N}, 150^{\circ} 22^{\prime} 38^{\prime \prime} \mathrm{W}\right)$. Calibrates varve counts in older part of core and dates volcanic ash beds derived from volcanoes on Alaska Peninsula. Sample helps date time of deglaciation of area previously thought to be much earlier (Karlstrom, 1964). Coll 1977 by J D Sims and M J Rymer; subm by J D Sims.

\section{USGS-338. Tangle Lake}

$4560 \pm 170$

$$
\text { Est } \delta^{13} C=-25 \% \text { o }
$$

Peaty sediments from core TNG-1 between 518 to $523 \mathrm{~cm}$ below bottom of Tangle Lake $\left(63^{\circ} \mathrm{l}^{\prime} 42^{\prime \prime} \mathrm{N}, 146^{\circ} 3^{\prime} 24^{\prime \prime} \mathrm{W}\right)$. Dates Holocene sedimentation and pollen accumulation in this area to $\mathrm{S}$ of Alaska Range that has adjacent archaeol sites. Coll 1977 by J D Sims and M J Rymer; subm by J D Sims.

\section{USGS-339. Tangle Lake}

$$
\begin{array}{r}
\mathbf{2 8 8 0} \pm \mathbf{7 0} \\
\text { Est } \delta^{13} \mathrm{C}=-25 \% \text { 。 }
\end{array}
$$

Peaty sediments from core TNG-1 between 233 or $237 \mathrm{~cm}$ below bottom of Tangle Lake ( $\left.63^{\circ} 1^{\prime} 42^{\prime \prime} \mathrm{N}, 146^{\circ} 3^{\prime} 42^{\prime \prime} \mathrm{W}\right)$. Dates Holocene sedimentation and pollen accumulation in this area to $\mathrm{S}$ of Alaska Range that has adjacent archaeol sites. Coll 1977 by J D Sims and M J Rymer; subm by J D Sims.

USGS-431. Hidden Lake, Kenai Peninsula

$2730 \pm 40$

Carbonaceous sediments from core HL-1-D between 74 and $79 \mathrm{~cm}$ below bottom of Hidden Lake $\left(60^{\circ} 29^{\prime} 37^{\prime \prime} \mathrm{N}, 150^{\circ} 22^{\prime} 38^{\prime \prime} \mathrm{W}\right)$. Calibrates 
varve counts in older part of core and dates volcanic ash beds derived from volcanoes on Alaska Peninsula. Coll by J D Sims and M J Rymer; subm by J D Sims.

\section{California}

USGS-68. Little Lake

$1440 \pm 130$ Little Lake Hotel, Little Lake ( $36^{\circ} 56^{\prime} 12^{\prime \prime}$ N, $117^{\circ} 54^{\prime} 24^{\prime \prime}$ W). Sample found $0.75 \mathrm{~m}$ below surface of alluvial gravels and indicates time when this horizon was at surface and occupied by man. Coll 1976 and subm by G I Smith, USGS.

\section{USGS-70. Mono Lake}

$$
\begin{array}{r}
2060 \pm 60 \\
\delta^{13} C=+6.6 \%
\end{array}
$$

Tufa on wood coll on $S$ shore Mono Lake ca $1.5 \mathrm{~km} \mathrm{~N}$ of Lee Vining $\left(37^{\circ} 58^{\prime} 42^{\prime \prime} \mathrm{N}, 119^{\circ} 67^{\prime} \mathrm{W}\right)$. Sample was $3 \mathrm{~m}$ above present lake level and gives indication of pre-nuclear era concentrations of ${ }^{14} \mathrm{C}$ in lake water. Coll 1976 and subm by G I Smith.

\section{USGS-222. Mecca}

$1090 \pm 40$ $\left(33^{\circ} 32^{\prime} 30^{\prime \prime} \mathrm{N}, 116^{\circ} 5^{\prime} \mathrm{W}\right)$ sedim chainage ditch bank in Lake Cahuilla $\left(33^{\circ} 32^{\prime} 30^{\prime \prime} \mathrm{N}, 116^{\circ} 5^{\prime} \mathrm{W}\right)$ sediments. Dates probable earthquake-induced deformational structures. Coll 1977 and subm by J D Sims.

\section{USGS-223. Mecca}

$1300 \pm 50$ sediments $\left(33^{\circ} 32^{\prime} 7^{\prime \prime} \mathrm{N}, 116^{\circ} 3^{\prime} 38^{\prime \prime} \mathrm{W}\right)$. Dates contain penecontemporaneously-formed probable earthquake-induced formational structures. Coll 1977 and subm by J D Sims.

\section{USGS-315. Blue Lakes, Lake County}

$2900 \pm 130$

Carbonaceous sediments from core below lake bottom of upper Blue Lake $\left(39^{\circ} 10^{\prime} 15^{\prime \prime} \mathrm{N}, 123^{\circ}\right.$ and $557.5 \mathrm{~cm}$ date level in core and provide estimate of sedimentation rate in this tectonically-controlled lake near Clear Lake, Lake Co. Coll 1977 by J D Sims.

\section{USGS-607. Willow Springs Fault}

$4590 \pm 120$

Charcoal from colluvial deposits displaced ca $70 \mathrm{~cm}$ on steep reverse

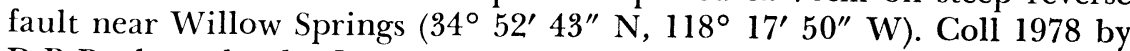
D B Burke; subm by C W Hedel, USGS.

\section{Koehn Lake series}

Lithoid tufa in near-surface gravel of pluvial lake shoreline bar in Fremont Valley $\left(35^{\circ} 22^{\prime} 40^{\prime \prime} \mathrm{N}, 117^{\circ} 48^{\prime} 55^{\prime \prime} \mathrm{W}\right)$, offset left-laterally ca $80 \mathrm{~m}$ along Garlock fault. Date is apparently that of most recent high-lake stand, but soil development in bar gravels indicates that bar construction 
was more than 100,000 yr ago. Coll 1978 by M M Clark; subm by D B Burke, USGS.

\section{USGS-634.}

$12,700 \pm 100$

Outermost rind, ca 2 to $4 \mathrm{~mm}$ thick.

$$
\text { Est } \delta^{18} C=0 \%
$$

USGS-635.

$13,460 \pm 80$

Inner rind, ca 3 to $5 \mathrm{~mm}$ thick.

$$
\delta^{13} C=3.0 \%
$$

\section{USGS-388. Koehn Lake}

$14,700 \pm 130$

$\delta^{13} C=4.6 \%$ o

Surface-water ostracodes from interstratified mud and fine sand in unoxidized deep-water deposits of most recent deep pluvial lake stand in Fremont Valley $\left(35^{\circ} 22^{\prime} 00^{\prime \prime} \mathrm{N}, 117^{\circ} 51^{\prime} 30^{\prime \prime} \mathrm{W}\right)$. Ostracode-bearing deposits have been deformed at least 9 and possibly as many as 17 times where they are offset by Garlock fault. Coll 1977 by M M Clark and D B Burke; subm by C W Hedel.

\section{USGS-337. Livermore Landslide, Napa Co}

$10,260 \pm 70$ $\left.\mathrm{N}, 122^{\circ} 34^{\prime} 14^{\prime \prime} \mathrm{W}\right)$. Date is min for last occurrence of slide movement. Coll 1977 and subm by R Witham, USGS.

\section{USGS-381. Clear Lake, Lake Co}

$18,500 \pm 230$

Est $\delta^{13} \mathrm{C}=-25 \%$

Carbonaceous sediments from Clear Lake Core 8 between 2037 and $2047 \mathrm{~cm}$ (lowermost $10 \mathrm{~cm}$ ) below base of Clear Lake $\left(39^{\circ} 5^{\prime} 48^{\prime \prime} \mathrm{N}, 122^{\circ}\right.$ $\left.51^{\prime} 42^{\prime \prime} \mathrm{W}\right)$. Dates level in core that has paleomagnetic stratigraphy and tephrachronology (Sims, 1976) and is correlated with seven other cores from lake. Coll 1977 and subm by J D Sims.

\section{USGS-382. Clear Lake, Lake Co}

$13,070 \pm 180$

Carbonaceous sediments from Clear Lake Core 3 between 890 and $900 \mathrm{~cm}$ below base of Clear Lake $\left(39^{\circ} 2^{\prime} 54^{\prime \prime} \mathrm{N}, 122^{\circ} 50^{\prime} 24^{\prime \prime} \mathrm{W}\right)$. Dates sedimentation rates and volcanic ash beds and helps correlate seven other cores from lake. Coll 1977 and subm by J D Sims.

\section{USGS-385. Castle Crag Soda Spring}

$$
\mathbf{p M}=\mathbf{2 . 9} \pm \mathbf{0 . 1 6 \%}
$$

Strontium carbonate precipitate formed by adding ammonical strontium chloride to $\mathrm{CO}_{2}$-charged spring water. Precipitation of strontium carbonate carried out at field site $\left(41^{\circ} 8^{\prime} 7^{\prime \prime} \mathrm{N}, 122^{\circ} 17^{\prime} 49^{\prime \prime} \mathrm{W}\right)$. Coll by R Mariner 1977; subm by Ivan Barnes, USGS.

$$
\text { Oregon }
$$

\section{USGS-343. Newberry caldera}

$$
\begin{array}{r}
4300 \pm 100 \\
\text { Est } \delta^{13} C=-25 \% \text { o }
\end{array}
$$

Silicified wood in pumiceous silicified lakeshore sediment ca $50 \mathrm{~m} \mathrm{~S}$ of interlake basaltic andesite flow along $\mathbf{E}$ shore of Paulina Lake at Little 
Crater campground $\left(43^{\circ} 00^{\prime} \mathrm{N}, 121^{\circ} 14^{\prime} 24^{\prime \prime} \mathrm{W}\right)$. Sediment is younger than palagonite tuff of Little Crater and interlake basaltic andesite flow and older than Mazama ash. Age is too young, based on presence of primary deposits of Mazama ash (6700-7000 вP) overlying sediment. Coll 1977 and subm by N S MacLeod, USGS.

\section{USGS-344. Newberry volcano}

$1550 \pm 120$ cano $\left(43^{\circ} 42^{\prime} 6^{\prime \prime} \mathrm{N}, 121^{\circ} 8^{\prime} 23^{\prime \prime} \mathrm{W}\right)$. Coll fro Hill Rd, $400 \mathrm{~m}$ N of overlain by $2 \mathrm{~m}$ of pumice fall and underlain by $0.8 \mathrm{~m}$ of Mazama ash. Date agrees with other date on pumice fall from near The Dome (W-2168, $1720 \pm 200$ вP, Spiker, Kelley, and Rubin, 1978). Coll 1977 and subm by N S MacLeod.

\section{USGS-755. Newberry caldera}

$1340 \pm 60$ Charcoal from burned trees incorporated in Paulina Lake ash flow $\left(43^{\circ} 42^{\prime} 36^{\prime \prime} \mathrm{N}, 121^{\circ} 15^{\prime} \mathrm{W}\right)$. Coll at same site, marked by concrete enclosure, from which previous samples were coll, C-657, $2054 \pm 230$ BP (Libby, 1952); W-2777, $1390 \pm 200$ вр (Kelley, Spiker, and Rubin, 1978); Tx-245, $1270 \pm 60$ BP (Pearson, Davis, and Tamers, 1966). Ash flow is virtually identical in major-\# and trace-element composition to youngest pumice fall on E flank of volcano (see USGS-344) and to Big Obsidian flow, and was redated to determine if pumice fall and ash flow are essentially same age or if ash flow is significantly younger; small age difference is suggested. Coll 1977 and subm by N S MacLeod.

\section{Washington}

\section{USGS-387. Garland Mineral Spring}

$$
\begin{array}{r}
\mathrm{pM}=\mathbf{4 . 1 3} \pm \mathbf{0 . 1 4 \%} \% \\
\text { Est } \delta^{13} \mathrm{C}=0 \% \text { o }
\end{array}
$$

Strontium carbonate precipitate formed by adding ammonical strontium chloride to $\mathrm{CO}_{2}$-charged spring water. Precipitation of strontium carbonate carried out at field site $\left(47^{\circ} 53^{\prime} 21^{\prime \prime} \mathrm{N}, 121^{\circ} 20^{\prime} 31^{\prime \prime} \mathrm{W}\right)$. Coll 1977 by R Mariner; subm by Ivan Barnes.

\section{USGS-386. Longmire Mineral Spring}

$$
\mathbf{p M}=\underset{\text { Est } \delta^{13} C=0 \%}{\mathbf{1 3}} \mathbf{0 . 1 2 \%}
$$

Strontium carbonate precipitate formed by adding ammonical strontium chloride to $\mathrm{CO}_{2}$-charged spring water. Precipitation of strontium carbonate carried out at field site in Mt Rainier Natl Park $\left(46^{\circ} 45^{\prime} 6^{\prime \prime} \mathrm{N}\right.$, $\left.121^{\circ} 48^{\prime} 48^{\prime \prime} \mathrm{W}\right)$. Coll 1977 by R Mariner; subm by Ivan Barnes.

\section{Steamboat Springs series}

\section{Nevada}

Bicarbonate and carbonate from thermal spring waters at Steamboat Springs $\left(39^{\circ} 23^{\prime} 18^{\prime \prime} \mathrm{N}, 119^{\circ} 44^{\prime} 25^{\prime \prime} \mathrm{W}\right)$. Values determined are used to study reservoir processes and flow patterns within geothermal system. 


\section{USGS-350. Near Spring 27}

USGS-365. Spring 26

USGS-366. Spring 5

USGS-367. Spring 8

$$
\begin{aligned}
& \mathrm{pM}=1.64 \pm 0.16 \% \\
& \delta^{13} \mathrm{C}=-5.9 \% \\
& \mathrm{pM}=0.46 \pm 0.16 \% \\
& \text { Est } \delta^{13} \mathrm{C}=0 \% \\
& \mathrm{pM}=1.21 \pm 0.12 \% \\
& \text { Est } \delta^{13} \mathrm{C}=0 \% \text { o } \\
& \mathrm{pM}=0.97 \pm 0.13 \% \\
& \text { Est } \delta^{13} \mathrm{C}=0 \% \text { o }
\end{aligned}
$$

Idaho

$$
2270 \pm 50
$$

Est $\delta^{13} C=-25 \%$ o

\section{USGS-318. Wapi Park}

Charcoal from charred roots of sagebrush found ca $2 \mathrm{~m}$ under edge of Wapi Lava Field at Wapi Park $\left(42^{\circ} 55^{\prime} \mathrm{N}, 113^{\circ} 15^{\prime} \mathrm{W}\right)$. Date agrees well with mean of previous dates on Kings Bowl Lava Field: Tx-1164, $2090 \pm 470$; Tx-1165, $2360 \pm 150 ; \times-1001,2130 \pm 130$ (Valastro, Davis, and Varela, 1978); Tx-1736, $2170 \pm 90$ (Valastro, Davis, and Varela, 1972) on charred material of similar origin. Combined with information that Wapi and Kings Bowl Lava Fields have identical directions of magnetization, dating suggests two eruptions occurred simultaneously. Coll 1977 by Ron Popson, Univ Arizona and subm by D Champion, USGS.

\section{REFERENCES}

Karlstrom, T N V, 1964, Quaternary geology of the Kenai Lowland and glacial history of the Cook Inlet region, Alaska: USGS Prof Paper 443, $69 \mathrm{p}$.

Kelley, Lea, Spiker, Elliott, and Rubin, Meyer, 1978, US Geological Survey, Reston, Virginia radiocarbon dates XIV: Radiocarbon, v 20, p 283-312.

Libby, Willard F, 1955, Radiocarbon dating, 2nd ed: Chicago, Univ Chicago Press, ix, $175 \mathrm{p}$.

Pearson, F J, Jr, Davis, E Mott, and Tamers, M A, 1966, University of Texas radiocarbon dates IV: Radiocarbon, v 8, p 453-466.

Sims, J I, 1976, Paleolimnology of Clear Lake, California, USA, Internatl symposium on global-scale paleolimnology and paleoclimate, in Horie, Shoji, Paleolimnology of Lake Biwa and the Japanese Pleistocene: Univ Kyoto, v 4, p 648-702.

Spiker, Elliott, Kelley, Lea, and Rubin, Meyer, 1978, US Geological Survey radiocarbon dates XIII: Radiocarbon, v 20, p 139-156.

Stuiver, Minze, and Polach, H A, 1977, Discussion: Reporting of ${ }^{14} \mathrm{C}$ data: Radiocarbon, v 19, p 355-363.

Valastro, S, Jr, Davis, E Mott, and Varela, Alejandra, G, 1972, University of Texas at Austin radiocarbon dates IX: Radiocarbon, v 14, p 461-485.

1978, University of Texas at Austin radiocarbon dates XII: Radiocarbon, v 20, p 245-273. 